\title{
Görüntülere Yansıyan Ortak Dil ve Toplumsal Hafıza: Türkiye ve Venezuela Askeri Darbelerine İlişkin Hazırlanan Belgesellerin Göstergebilimsel Analizi
}

\section{Images Reflected Common Language and Social Memory: Semiotic Analysis Of The Prepared Documentary on The Military Coup in Turkey and Venezuela}

Onur Önürmen, ${ }^{\mathrm{a}, *}$ Faruk Temel b

${ }^{a}$ Dr. Öğr. Üyesi, Erciyes Üniversitesi, İletişim Fakültesi, Radyo Tv Sinema Bölümü, Kayseri/Türkiye. ORCID: 0000-0001-7500-2869

bDr. Öğr. Üyesi, Erciyes Üniversitesi, İletişim Fakültesi, Gazetecilik Bölümü, Kayseri / Türkiye. ORCID: 0000-0001-7103-0790

\section{MAKALE BİLGİSI}

\section{Makale Geçmişi}

Başvuru tarihi: 01 Eylül 2019

Düzeltme tarihi: 01 Aralık 2019

Kabul tarihi: 06 Aralık 2019

\section{Anahtar Kelimeler:}

İletişim Araçları,

Teknoloji,

Askeri Darbe,

Türkiye,

Venezuela,

Darbe

\section{A RTICLE INFO}

\section{Article history:}

Received 01 September 2019

Received in revised form 01 December 2019

Accepted 06 December 2019

\section{Keywords:}

Communication Tools,

Technology,

Military Coup,

Turkey,

Venezuela,

Coup
ÖZ

İletişim araçlarının gelişimi, siyasal ve toplumsal alışkınlıkların da değişimini ortaya çıkarmıştır. Tarihten bugüne çeşitli toplumlarda görülen askeri güç odaklarının yönetimi ele geçirme girișimlerinin özellikle son dönemde sekteye uğratılmasında iletişim araçları ve teknolojik ilerlemelerin önemli payı vardır. 2002 yılında Venezuela'da, 2016 yılında Türkiye'de gerçekleştirilmek istenen askeri darbe girişimlerinin püskürtülmesi bu duruma örneklik teşkil etmektedir. Bu bağlamda Venezuela'da (2002) ve Türkiye'de (2016) gerçekleştirilmek istenen başarısız darbe girişimlerine ilişkin hazırlanan "The Revolutıon Will Not Be Televised" ve "15 Temmuz Destanı" adlı belgeseller göstergebilimsel analiz yöntemiyle incelenmiştir. Araştırma neticesinde; toplumsal bütünlügün sağlanmasında tarihi, kültürel ve dini değerlerin önemli unsurlar olduğu, değerler bütününün sunumu ve toplumun kanalize edilmesinde de sosyal medya ve geleneksel medya gibi araçların üretimlerinin etkin olduğu saptanmıştır.

\section{A B S T R ACT}

The development of communication tools has revealed the change of political and social habits. Communication tools and technological advances have played an important role in the recent disruption of the attempts by the military power centers in various societies since history to seize management. In 2002, in Venezuela, in 2016, to take place in Turkey spraying the desired military coup poses exemplary in this situation. In this context, Venezuela (2002) and Turkey (2016), prepared for the desired unsuccessful coup attempt carried out to "The Revolution Will Not Be Televised" and "15 July Epic" documentary were examined. In a comparative approach, documentaries examined by semiotic analysis are the sample of the research. As a result of the research; It has been determined that historical, cultural and religious values are important factors in ensuring social integrity, and the production of tools such as social media and traditional media are effective in the presentation of the whole values and channeling the society.

\section{Giriș}

İnsanların bir düzen içinde ve bir arada yaşayabilmesinin en temel koşullarından biri, rızanın sağlanmasıdır. Söz konusu rızanın sağlanması için egemen güçler tarafından topluma kimi zaman otoriter ve baskıcı kimi zaman da daha yumuşak, oydaşım sağlayıcı yöntemlerle müdahale edilmektedir. Bununla birlikte bazen de silahlı gruplar siyasi birtakım saiklerle yönetimi ele geçirmek adına zorbaca girişimlerde bulunmaktadırlar. $\mathrm{Bu}$ şekilde ortaya çıkan ve darbe olarak nitelendirilen durumlar sonrasında çeşitli toplumsal travmalar

\footnotetext{
* Sorumlu yazar/Corresponding author

e-posta: onurmen@erciyes.edu.tr
} 
ortaya çıkmaktadır. Bunun sonucunda etkisi nesillerce sürecek kamplaşma ve kutuplaşmalar meydana gelmekte, toplumsal rızanın üretilmesi daha güçleşmektedir. Rızanın üretilmesinde ve dolayısıyla hegemonyanın sürdürülmesinde medyanın rolü büyüktür. Gramsci(2014, s. 347) klasikleşmiş parlamenter sistemlerde egemenliğin işleyişinin güç ve rıza arasındaki denge ile sağlandığını belirterek, gücün ağır basmadığı izleniminin uyandırılmaya çalışıldığını vurgular. Ona göre güç ve rıza arasında bir sahtecilik durumu mevcuttur ve çeşitli gazeteler veya dernekler gibi kamuoyu organları vasıtasıyla kimi zaman yapay biçimde çoğaltılarak, çoğunluğun rızası oluşmuş gibi gösterilmektedir. Bu noktadan bakıldığında medyanın, yönetimi elinde bulunduran egemen güçlerin işlevsel bir aygıtı olduğunu söylemek mümkündür. Zira medya, yaşam tarzlarının oluşturulmasından, değiştirilmesine, ekonomik karar verme süreçlerinden siyasi karar verme süreçlerine kadar pek çok konuda etkin bir araç konumundadır. Bununla birlikte, kitlelere iletilen mesajların yanı sıra iletilmeyen mesajlarla da toplumsal düşünce yapısı şekillendirilmekte ve yönlendirilmektedir. Dolayısıyla herhangi bir iktidar türünün egemenliğini sürekli hale getirmesi için, hükmettiği toplulukların zihinsel yapısını da şekillendirmesi gerekliliği ortaya çıkmaktadır. Bu da en hızlı, yumuşak ve kitlesel biçimde, medya yoluyla gerçekleştirilebilmektedir.

$\mathrm{Bu}$ bağlamda çalışmada, yakın geçmişte benzer siyasal süreçlerden geçen Venezuela'da ve Türkiye'de başarısız olan darbe süreçlerini yansitan belgeseller incelenmektedir. Venezula'da 2002 yılında gerçekleşen başarısız darbe girişimi ${ }^{1}$ sürecini anlatan The Revolution Will Not Be Televised adl belgesel ve 15 Temmuz 2016'da Türkiye'de gerçekleştirilmek istenen darbe girişiminin ${ }^{2}$ püskürtülmesi sürecini anlatan 15 Temmuz Destanı adlı belgesel Youtube'da yayımlanmıştır. Bu belgesellerin, darbe süreçlerini yansıtması ve sonrasında yaşananların toplumsal belleğe aktarılmasındaki rolü, belgesel videolarının göstergebilimsel analiz yöntemiyle karşılaştırılarak incelenmesiyle saptanmıştır.

\section{Toplumsal Hatırlamanın Aracı ve İdeolojik Aygıt Olarak Medya}

Medya, hâkim sınıf ile onun karşıtları arasındaki mücadelenin en çok görünür olduğu alanlardan biridir. Dolayısıyla aynı zamanda kamuoyunun düşüncesini etkileyebilmek adına pek çok yazılı, işitsel ya da görsel argümanın, söylemin ortaya konduğu bir propaganda alanıdır. Aziz (2007, s. 15)propaganda kavramını işlevsel bir bakış açısıyla tanımlayarak mesajların otoriter bir biçim ile tek taraflı olarak tutum ve davranışları değiştirmesi amacıyla kullanılan bir yöntem olarak ifade etmektedir. Buradan hareketle geleneksel medyanın yapısal özellikleri itibariyle propaganda için uygun bir mecra olduğunu söylemek mümkündür. Ne var ki, özellikle geleneksel medyanın mülkiyet yapısı, bu argüman ve söylemlerin ne sıklıkla veya hangi frekanslarda yayımlanacağı konusunda belirleyicidir. İçeriğe ilişkin bazı hukuki, teknik

\footnotetext{
${ }^{1}$ Venezuela'da "Bolivarcı Devrim" adıyla anayasanın değiștirilmesi, yerleşik petrol şirketlerinin, Katolik kilisesinin, iş adamlarının ve ülkedeki Hugo Chavez karşıtlarının memnuniyetsizliğine yol açmış ve 11 Nisan 2002 'de bir darbe girişiminde bulunulmuştur. Darbe girişimi başarısız olmuş ve Hugo Chavez iki gün içerisinde tekrar görevine dönmüştür.
}

veya etik kaygılar, yayın teknolojisi, dağıtım ve fiyatlandırma gibi sebeplerle birleşince medyanın sunmuş olduğu bu propaganda alanı muhalif kesim için daralmaktadır. Mülkiyet ve reklamla ilgili dolayımlar -bilhassa- geleneksel medyanın ekonomik gücü elinde bulunduranlara bağımlı olması sonucunu ortaya çıkarmaktadır (Shoemaker \& Reese, 2002, s. 148). $\mathrm{Bu}$ durum ise geleneksel medyanın hakim güçlerin söylemlerinin yeniden üretilmesini ve pekiştirilmesini sağlayan ideolojik aygıt olarak iş gördüğünü kanıtlar niteliktedir.

Geleneksel medyanın yapısal sorunlarına karşılık, yeni medya olgusunun ortaya çıkışı ile yukarıda sözü edilen mücadele alanının görece daha yakın koşullara taşındığını söylemek mümkündür. Bununla birlikte yine geleneksel medya şirketleri dijital ortama taşınmış ve hem kendi web siteleri hem de sosyal ağlarda yönettikleri sayfalarla varlıklarını devam ettirmişlerdir. Kullanıcı kaynaklı içerik üretimi, geleneksel medyanın söylem üretim alanına kısmen de olsa ortaklık etmiştir. Yeni medyanın hızlı, sık güncellenen ve en azından bağımsız görünen yapıs1, siyasal mücadele ve propaganda pratiklerini dönüştürerek, işleyiş yönüyle daha hantal olan geleneksel medya içeriklerine etki eden bir hal almıştır. Castells (2012, s. 29) bu durumu, siyasal aktörlerin interneti geleneksel medyanın gündemini etkilemek amacıyla kullandığını vurgular ve internet tabanlı yeni medyanın sunduğu olanaklar sayesinde gittikçe daha fazla bu platformları kullandığını belirtir.

Günümüzde dünya çapındaki sosyal ağların milyonlarca kullanıcıya ulaşması ve özellikle taşınabilir cihazlar sayesinde enformasyonun her an ve her yerden iletilebilir hale gelmesi, bilgiyi sınırlandırma ya da engelleme girişimlerini de sonuçsuz bırakmaktadır.

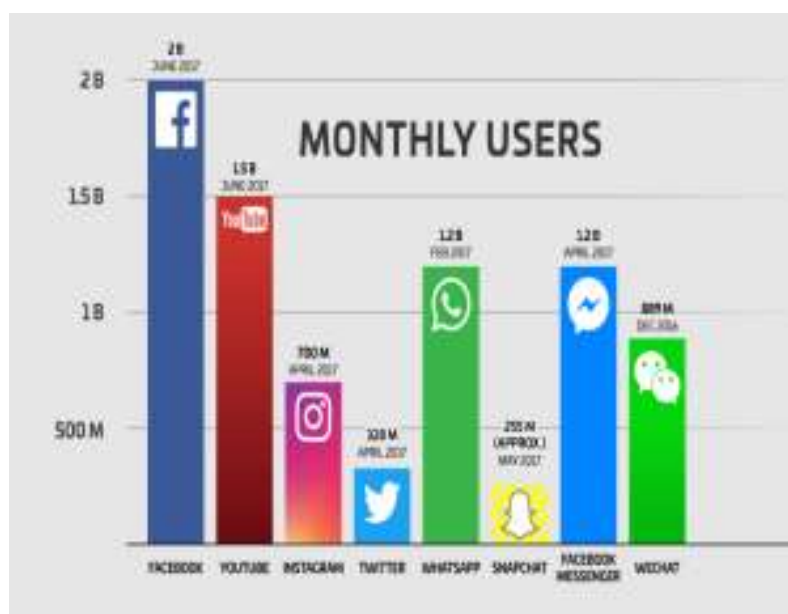

Tablo.1) Çeşitli sosyal ağların 2017 yılı itibariyle kullanıcı sayıları ${ }^{3}$

Enformasyon üretiminin ve dağıtımının bu denli hızlandığı, küresel bir boyuta evrildiği günümüzde medya yoluyla rıza üretiminde de biçimsel birtakım değişmeler olduğu

\footnotetext{
2 Devlet içinde illegal olarak faaliyet gösteren Fettullahçı Terör Örgütü / Paralel Devlet Yapılanması (FETÖ / PDY) tarafından devleti ele geçirmek üzere TSK'da yuvalanan teröristlerce 15 Temmuz 2016 tarihinde gerçekleştirilmek istenen ancak devlet ve millet ortaklığıyla püskürtülen darbe girişimidir.

${ }^{3}$ https://techcrunch.com/2017/06/27/facebook-2-billion-users/ (erişim tarihi: 08.08.2018)
} 
görülmektedir. Egemen gruplar ve onların temsilcileri artı yeni medya yoluyla da propaganda yapma ve kitlelerde riza oluşturma çabalarını sürdürmektedirler. Buradan hareketle, simge ve sembollerin ortaklaştırılması, bunların belirli sıklık ve yoğunlukla, farklı mecraların biçim ve içerik kodlarına uygun biçimde üretilmesi, paylaşılması ve yaygınlaştırılması hem hegemonyanın hem de hegemonya karşıtlarının yeni bir mücadele alanında karşı karşıya gelmesini sağlamıştır. Diğer yandan bu ortaklaştırma mücadelesinin toplumsal düzeyde istenilen sonuçlara ulaşabilmesi için bir organizasyon ve düzen çerçevesinde olması gerekmektedir.

Medya; gündelik hayata dair pek çok işlevi/etkisi olan bir platform olmasının yanı sıra -yeri geldiği zaman başvurulmak üzere kullanılan- bilgi ve bellek platformu olarak da kullanılmaktadır. Kolektif hatırlamanın toplumsal organizasyonu, Wertsch'in(2015, s. 169) ortaya koyduğu bir kavram olarak, genel hatlarıla topluluk üyelerinin bilgi, inanç, deneyim vb. düzeylerinin birbirinden farklı olabileceğini ileri sürmekte ve kitleleri ortak anlatılar ve metinler/kaynaklar vasıtasıyla bir araya getirilebileceğini ifade etmektedir. Bu noktada anlatıların nasil ve kim tarafindan şekillendirileceği sorusu ortaya çıkmaktadır. Yakın bir zaman dilimine kadar kolektif hatılamanın ortak anlatı, simge ve sembolleri geleneksel medya araçları vasitasıla üretilmekteydi. Günümüzde ise geleneksel medyanın meslek profesyonelleri sayesinde ortaya çıkan anlatı üretme gücü nispeten azalarak, yerini mobil uygulamalar ve cihazlar vasitasıyla profesyonel olmayan kişilerin de kitleler için ortak anlatı ve semboller üretmesine bırakmıştır. Başka bir deyişle, geleneksel medya, yeni medyada üretilen içeriklerin öne çıkanlarının yayıldığı, yaygınlaştırıldığı bir mecra haline gelmiştir. Bununla birlikte yerleşik yapısı ve kullanım alışkanlıkları nedeniyle geleneksel medya hala daha güçlü bir anlam üretim mekanizmasıdır. Dünyanın farklı coğrafyalarında da görüldüğü üzere bilhassa kriz dönemlerinde önemli bir referans kaynağı olarak öne çıkmaktadır. Diğer taraftan medyanın ortak bir belleği daha çok görsel imgeler aracılığıyla oluşturduğunu söylemek mümkündür. Çilingir ve Dursun'un (2017, s. 351) gerçeklik aktarımı olarak ifade ettikleri bu durum sayesinde toplumsal bellek oluşumu ve kültürel hafiza oluşumları meydana gelmektedir. $\mathrm{Bu}$ süreç esnasında materyaller, kimi zaman gerçek görüntüler, canlı tanıkların anlatımları, tarihi kaynaklar kimi zaman da akademik bir bakış açısıyla veya sözlü anlatım geleneği içerisinde birleştirilerek kullanılabilmektedir. Böylelikle yalın bir gerçeklik, kurgusal bir süreçten geçerek bireysel ve toplumsal bellekte yer etmektedir.

Seçilmiş bir siyasal iktidarı devirmek amacıyla silahlı bir baskı oluşturma yöntemi, geçmişte geleneksel medya kanallarını ve bilgi akışının denetimini ele geçirerek nispeten daha kolay uygulanmaktaydı. Çünkü bu baskı durumunun hak ihlallerini ve kötü muamelelerini kamuoyunun gündemine taşıyacak, toplumsal belleği diri tutacak ve muhalif söylemi oluşturacak iletişim kanalları sınırlı sayıda ve fiziki bir biçimde ele geçirilmesi kolay bir haldeydi. Günümüzde ise yeni medya, internet teknolojisi, mobil iletişim cihazları (akı1lı telefon, tablet vb.) ve sosyal medya uygulamaları sayesinde bu bilgi akışı ve bellek oluşturma yetisi çeşitlenmiş ve her kullanıcının aynı zamanda bir içerik üreticisi olmasına yol açmışırı. Özellikle toplumsal olayların kaydedilmesinde, yayımlanmasında ve istenildiği zaman yeniden erişilebilmesinde video paylaşım sitelerinin etkisi büyüktür. $\mathrm{Bu}$ bağlamda dünya çapında önemli bir video paylaşım sitesi olan Youtube, 15 Temmuz Darbe Girişimi'ne ilişkin görüntülerin de saklandığı ve paylaşıldığı bir arşiv platformu haline gelmiştir. Yine aynı biçimde The Revolution Will Not Be Televised adlı belgesel de geleneksel medya için çekilmesine rağmen yine aynı mecrada yerini almaktadır.

\section{Yöntem}

Çalışma nitel bir çalışmadır. Birbirine benzer tarihsel-siyasi süreçleri konu alması ve aynı mecrada (Youtube) paylaşılması nedeniyle 15 Temmuz Destanı ve The Revolution Will Not Be Televised belgeselleri ile sinırlandırılmıştır. Bu bağlamda çalışmaya konu olan her iki belgeselin ilettiği görsel mesajların ortaya çıkarılması, benzer imgelerin tespiti ve çözümlenmesi adına göstergebilim yöntemi tercih edilmiş̧ir. Bu doğrultuda ilk olarak belgesellerde yer alan göstergeler ve anlamlarına odaklanılmış̧ır. Saussure'a göre göstergeler sonucunda toplumsal bir dizge olan dil oluşur. Dilsel gösterge iki parçalıdır, bunlardan biri dilin işitim imgesi diğeri ise kavramdır. Bunlara gösteren ve gösterilen adı verilir. (Rifat, 1998) Dolayısıyla belgesel filmleri bir metin olarak değerlendirdiğimizde bu metnin anlaşılabilmesi ve karşılaştırılabilmesi için kendi dilsel dizgelerinin söz konusu kavramların ışığında değerlendirilmesi gerekmektedir.

Adanır (2003, s. 77) Barthes'a göndermede bulunarak, tıpk1 edebiyat gibi sinemanın da dünyayı özgürlüğe kavuşturacak bir araç olmadığını ifade eder. Ona göre sanatçının film vasıtasıyla yaptığı seyircinin sıkıştırılan beynini kısa süreli bir gevşetmeye eşdeğerdir ve sinemanın insanlığa en büyük faydasının insanların birbirlerine benzediklerini, acılarının, sevinç ve hüzünlerinin ortak köklere dayandığını göstermesidir. Bu anlamda iki farklı ülkede meydana gelen olayları konu alan belgesellerdeki ortak anlatım unsurlarının bulunması, bu ortaklıkların hangi imgelerle ifade edildiğinin ortaya çıkarılması açısından göstergelerin, düz ve yan anlamlarının saptanması gerekmektedir. Barthes'a (1979, s.89) göre metin incelemelerinin geleceği yan anlam incelemelerindedir, çünkü toplum, durmadan dil vasitasıyla oluşturduğu birinci dizgeden yola çıkarak ikinci anlam dizgelerini geliştirir. Kendisi de bir dizge olan yan anlam, gösterenler, gösterilenler ve bunları birbirine bağlayan bir oluşu kapsar. Dolayısıyla her dizgede anlam düzeylerini bulabilmek için, ilk başta, bu üç öğenin dökümünü yapmak gerekir.

Bu doğrultuda çalışmada Barthes'ın da yukarıda değindiği üç ögenin dökümünü yapmak amacıyla her iki film içerisinde de yer alan ortak/benzer imgeler tespit edilmiş, gösterge gösteren - gösterilen ögelerinin dökümü oluşturulmuş sonrasında bunların anlamsal boyutları değerlendirilmiştir. Ardından her iki belgesel için yayınlandıkları mecra dolayısıyla nicel bilgilerin yer aldığı bir künye hazırlanmış ve bulgular kısmında verilmiştir. Ardından belgesellerin olay/zaman örgüsü aktarılmıştır. Daha sonra ise belgesellerdeki görüntüler gösteren, gösterilen ve gösterge başlıkları altında tablo halinde sunulmuş ve elde edilen veriler bu bağlamda değerlendirilmiştir. 


\section{Bulgular ve Yorumlar}

15 Temmuz Destanı Belgeselinin Göstergebilimsel Analizi

Tablo 1. 15 Temmuz Destanı adlı belgeselin künyesi

Başlık 15 Temmuz Destanı Belgeseli

Kullanıcı Adı Ekonomi Kulübü

\begin{tabular}{ll}
\hline Url & $\begin{array}{l}\text { https://www.youtube.com/watch?v=08YG3v5- } \\
\text { zCQ\&t=1380s }\end{array}$ \\
\hline Süre & $27 \mathrm{dk} .22 \mathrm{sn}$. \\
\hline $\begin{array}{l}\text { Yükleme } \\
\text { tarihi }\end{array}$ & 28 Temmuz 2016 \\
\hline
\end{tabular}

Görüntüleme $\quad 409.386(25.02 .2017$ itibariyle $)$
sayıs1

\begin{tabular}{ll}
\hline Beğenilme & 2809 \\
\hline Beğenilmeme & 100 \\
\hline Yorumlar & Yoruma kapalı \\
\hline Etiket & Yok \\
\hline Tanım & $\begin{array}{l}\text { "Ekonomi Kulübü tarafından hazırlanan ve } \\
\text { Temmuz Destanı belgesiyle darbe girişiminin } \\
\text { tüm sayfalarını ortaya koymak ve milletimizin } \\
\text { destansı direnişini gelecek nesillere aktarmak } \\
\text { için yapılmıştır. Bugüne kadar verdiğimiz } \\
\text { şehitlerin yanına uğurladığımı 15 Temmuz } \\
\text { şehitleri her zaman dualarımızda olacak..." }\end{array}$
\end{tabular}

Belgeselin girişinde Başkent Ankara'nın kuşbakışı bir genel görüntüsünün ardından yine havadan bir Kocatepe Camii görüntüsü, sonrasında Ankara'nın sembol mimari yapılarından biri olan Atakule'nin görüntüsü, Ulus-Hitit heykeli ve Beştepe Cumhurbaşkanlığı Külliyesi görüntüleri arka arkaya verilmiştir. $\mathrm{Bu}$ görüntüler Türkiye'nin tarihsel kültürel ve siyasal geçmişine vurgu yapmaktadır. Bunun yanı sıra son olarak gösterilen Cumhurbaşkanlığı Külliyesi de bu girişimin doğrudan devlete ve cumhurbaşkanına yönelik olduğunu göstermektedir. Belgeselde daha sonra Fetö/PDY lideri Fethullah Gülen'in bir vaaz videosunda hâlihazırdaki hükümeti ve cumhurbaşkanını ima ederek sarf ettiği beddua sözlerine yer verilmiştir. $\mathrm{Bu}$ görüntüler Fethullah Gülen'in darbe girişiminin planlayıcısı ve azmettiricisi olduğunu ve yaşanan darbe girişimini başlatan örtülü mesajın bu olduğunu vurgulamaktadır. Ardından çeşitli arşiv görüntüleri ile girişimin gerçekleşmesine kadar üst düzey güvenlik bürokrasisinde yaşanan gelişmeler ve ortaya çıkan kimi sorular aktarılmıştır. $\mathrm{Bu}$ vesileyle MiT Müsteşarı Hakan Fidan ve Genelkurmay Başkanı Hulusi Akar'ın çeşitli toplantılara geliş ve gidiş görüntülerine yer verilmiş ve kurgu ile izleyici de darbe girişimi öncesi bir gerilim yaratılması amaçlanmıştır. Diğer yandan belgesel boyunca ekranın sol alt köşesinde anlatılan olayların saat ve yer bilgisi aktarılarak olaylar izleyiciye hem kronolojik bir düzen içinde anlatılmış hem de heyecan duygusunun yaratılması hedeflenmiştir.

Belgeselin giriş kısmında bu materyallere yer verildikten sonra darbe girişimi esnasında yaşananlar ekrana yansıtılmıştır. Güvenlik kameralarından elde edilen ve caddelerde gezen tank, zırhlı araç vb. görüntüleri kullanılarak yaşanan panik ve şaşkınlık durumu vurgulanmıştır. Sonrasında bir amatör kamera çekimi vasıtasıyla halkın üstüne helikopterden açılan ateş görüntülerine yer verilmiş, ardından Ankara ve İstanbul'da gerçekleşen çeşitli saldırı ve işgal eylemleri aktarılmıştır. Görüntülerde panik halinde kaçışan halk ve bombalanan kamu binaları bulunmakta, böylelikle söz konusu darbe girişiminin en başından itibaren yarattığı dehşet ve infial ortamı vurgulanmaktadır.

Bununla birlikte halkında küçük gruplar halinde bu duruma direniş göstermeye başladığı görülmektedir. İstanbul Atatürk Havalimanı'na el koyan darbeci askerleri protesto etmeye giden halk1 gösteren görüntüler de dikkat çeken en önemli detaylardan biri de vatandaşların akıllı telefonları ve amatör kameralarıyla olup biteni kaydetmesidir.

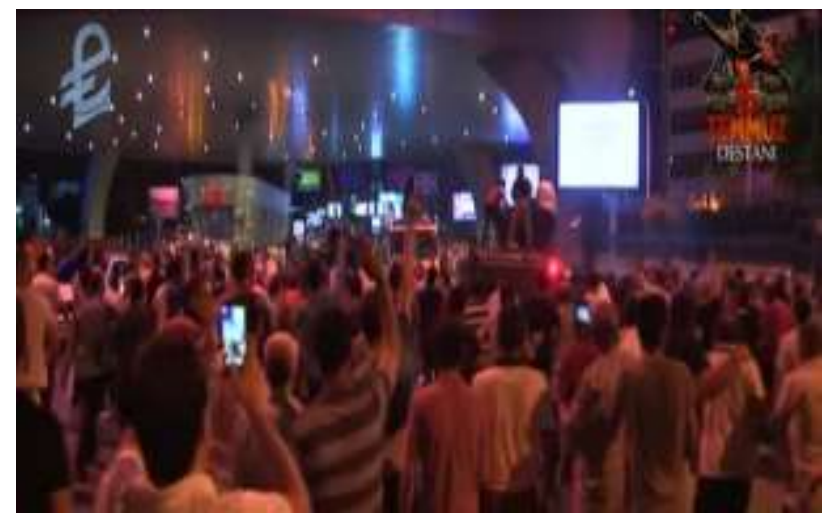

Görsel.1) 15 Temmuz Destanı belgeselinden bir kare.

Bu durum henüz TV ya da radyo gibi geleneksel kitle iletişim araçlarında darbe girişimi hakkında haber verilmemesine rağmen, sosyal medya ve mobil iletişim araçlarıyla halkın durum hakkında bilgi sahibi olmaya ve tepki vermeye başlamasının bir göstergesidir. Hemen ardından saat 22.50'de Başbakan Binali Yıldırım'ın olayla ilgili NTV televizyonuna yaptığ 1 canlı telefon bağlantısının görüntüleri verilmiştir. $\mathrm{Bu}$ da yaşanan girişimin ilk kez -hükümetin başındaki isim olması nedeniyle- doğrudan hedeflerinden biri olan Başbakan Binali Yıldırım tarafından hem Türkiye hem de dünya kamuoyuna resmen duyurulmasina da vurgu yapmaktadır.

$\mathrm{Bu}$ görüntülerin ardından darbeye direniş gösteren halkın üzerine açılan ateş görüntüleri ve yaşanan çatışmalar aktarılarak, geçmiş dönemlerde de yönetime el koyan ancak halkın tepkisi ile karşılaşmayan darbeci askerlerin ilk kez karşılaştıkları bu direnişe karşı sert ve acımasız bir tavır takındıkları vurgulanmıştır. Ardından darbecilerin TSK internet sitesinde yayınladıkları darbe bildirisi ekranlara yazılı olarak yansıtılmıştır. Bildiride geçen ve anayasal düzene demokrasi insan hak ve özgürlüklerine vurgu yapan cümleler ekranda akarken, arka planda sokaklarda gezen tanklar ve onları protesto eden halkın görüntüleri ironik bir durum oluşturmaktadır. Devam eden protesto görüntülerinde vatandaşların akıllı telefonlarıyla çekim yapmaları ve protestolarında herhangi bir siyasi parti ya da sivil toplum kuruluşunun bayrağını veya flamasını taşımadıkları, yalnızca Türk bayrağı ile sokaklara çıktıkları görülmektedir. $\mathrm{Bu}$ 
görüntüler Widgington'ın video aktivizm ile ilgili olarak ileri sürdüğü "dünyanın her yerinden gelen bu tür içerikler çoğaldıkça daha kolay paylaşılıp, erişildikçe; farklı mücadelelerin birbirine bağlandığ1 ve daha çok görüntünün daha büyük bir kitle tarafindan izlenmesine ve bunun onları endişelendikleri durum / sorun hakkında eyleme geçtiği ve bilgi dağarcıklarını genişlettiğii" tezi ile de uyumludur. (Widgington, 2015, s. 126) Zira kamu yayıncılığı yapan TRT de darbecilerin eline geçmiş,ülkedeki diğer önemli haber kanallarına baskınlar yapılmış ve yayın yapmalarını sağlayan verici istasyonları bombalanmıştır. $\mathrm{Bu}$ nedenle güvenilir haber kaynağı olarak bir takım özel TV kanalları ve sosyal medya kalmıştır. Facebook, Periscope vb. platformlar üzerinden yapılan canlı yayınlar, yine diğer sosyal medya platformları üzerinden paylaşılan video ve fotoğraflar hem gelişen olay hakkında anlık, hem de sonrasında bir belge bir kanıt olması nedeniyle tarihsel bir farkındalık oluşturma yetisi göstermiştir.

Ardından gelen görüntülerde TRT canlı yayınında darbe bildirisinin okunması verilmiştir. Kamu yayıncılığı yapan ve aynı zamanda resmi bir kurum olan TRT, cumhuriyet tarihi boyunca gerçekleştirilen darbe girişimlerinin halka duyurulmasında ve böylelikle değişen hegemonik durumun benimsetilmesinde kilit rol oynamıştır. Bu nedenle toplumsal bellekte böyle bir yeri olan TRT'nin ele geçirilmesinin aktarılması önemli bir psikolojik eşiğe karşılık gelmektedir.

Belgeselde daha sonra Cumhurbaşkanı Recep Tayyip Erdoğan'ın kendisini ölü ya da diri ele geçirmek isteyen darbeci askerleri nasıl atlattığı anlatılmış ve sonrasında bu girişime karşı topyekün bir direniş gösterilmesi için $\mathrm{CNN}$ TÜRK televizyonunda bir akıllı telefon uygulaması olan FaceTime $^{4}$ ile gerçekleştirdiği canlı bağlantıya yer verilmiştir. Söz konusu görüntü, yeni medya ile geleneksel medyanın amaç, teknoloji ve etki bağlamında yakınsadıkları, tarihsel öneme sahip bir ana vurgu yapmaktadır. Aynı zamanda eldeki kısıtlı imkanlar doğrultusunda halka direnişe geçme ve darbecilere ise seçilmiş yöneticiler olarak boyun eğilmeyeceği mesajının verilmesi anlamında bir kararlılığı da göstermektedir.

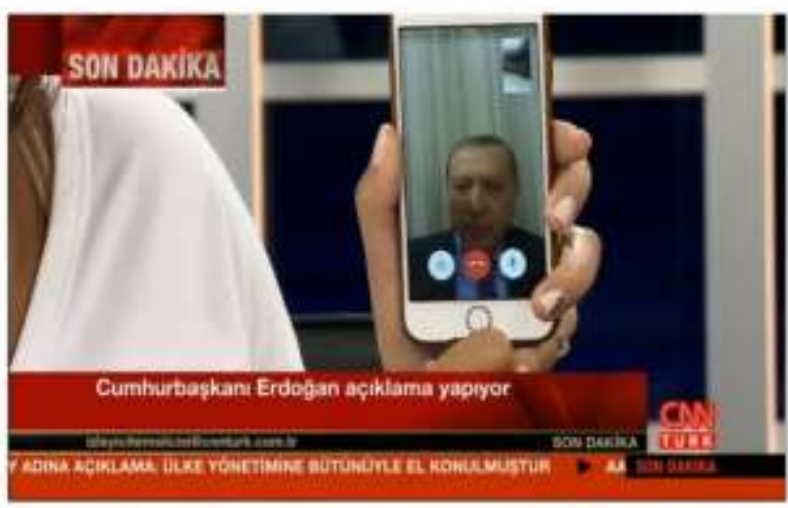

Görsel.2.) 15 Temmuz Destanı adlı belgeselden bir kare

Bu çağrının ardından belgeselde halkın daha yoğun biçimde sokaklara çıktığı görüntülere yer verilmiştir. Amatör kamera çekimlerinden yansıyan görüntülerde, çoğunlukla genç ve erkek göstericiler, ellerinde Türk bayrağı olduğu halde meydanlarda toplanmakta ve kol kola yürümektedirler.

Görüntüler cumhurbaşkanının çağrısının halkın çok büyük bir kısmında cevap bulduğunu ve etnik, dini ve siyasi görüş fark1 olmaksızın darbeye karşı direnişin tüm ulusun ortak sembolü olan bayrak altında toplandığını göstermektedir. Bayrak, ulusun bağımsızlığını simgeleyen bir gösterge olduğu için, darbeye karşı direnişe geçen halkın bu sembolle, girişimin ardındaki dış güçlere karşı da tepkisini gösterdiği mesajı anlaşılmaktadır.

Halkın direnişinin giderek güçlenmesi ve darbe girişimine destek vermeyen polis ve asker gruplarının da darbecileri engellemeyi çalışmaları, yaşanan çatışma ve bombalama eylemlerinin artmasına ve şiddetlenmesine neden olmuştur. Güvenlik kameraları ve amatör çekimler vasıtasıyla aktarılan bu görüntüler, yaşanan olayların ciddiyetini göstermektedir. Bununla birlikte, bu dehşet veren ve panik yaratan adeta bir savaş atmosferini çağrıştıran olaylar içinde bile halkın akıllı telefonlar, amatör video kayıt cihazları vb. vasıtasıyla çekim yapması, bunları sosyal medya platformlarında paylaşması; bu tür medya araçlarının kullanımının ve etkisinin doğallaştığını ve benimsendiğini göstermektedir.

Belgeselin ele aldığı konu doğrultusunda öne çıkan görüntülerin göstergebilimsel tablosu aşağıdaki gibidir.

Tablo 2. Gösteren, gösterilen ve göstergeler tablosu

\begin{tabular}{|c|c|c|}
\hline Gösterge & Gösteren & Gösterilen \\
\hline Türk Bayrağ1 & $\begin{array}{l}\text { Egemenlik, } \\
\text { bağımsızlık }\end{array}$ & Ulusal Birlik \\
\hline Cami & Taş Bina & $\begin{array}{l}\text { Dindaşlık, } \quad \text { dini } \\
\text { aidiyet }\end{array}$ \\
\hline $\begin{array}{ll}\text { Mustafa } & \text { Kemal } \\
\text { ATATÜRK } & \end{array}$ & Tasblo & $\begin{array}{l}\text { Ülkeyi düşmandan } \\
\text { kurtarma, direniş }\end{array}$ \\
\hline TBMM & Tarihi bina & $\begin{array}{l}\text { Halk iradesinin } \\
\text { görünür olduğu yer }\end{array}$ \\
\hline $\begin{array}{l}\text { Terkedilen Askeri } \\
\text { Araçlar, } \\
\text { Tutuklanan } \\
\text { Askerler }\end{array}$ & Araç, İnsan & $\begin{array}{l}\text { Halkın zaferi } \\
\text { Darbecilerin } \\
\text { kaçışı, } \\
\text { yakalanışları. }\end{array}$ \\
\hline
\end{tabular}

Belgeselde verilmek istenen mesajların ortaya çıtı̆̆ 1 , farkındalığın yaratılmasına hizmet eden bu görüntülerin, anlatıcı ses, müzik, yazı vb. efektlerle birlikte bilinçli birer tercih olarak kullanıldığı anlaşılmaktadır.

Darbe girişiminin gerçekleştiği gece camilerden verilen sela görüntüleri, halkla seçilmiş yöneticilerin iletişiminin sağlanması, direnişin devam etmesi, bu girişime karşı çıkmanın bir vatandaşlık ve inanç gereği olduğu mesajını vurgulamaktadır. $\mathrm{Bu}$ noktadan bakıldığında söz konusu görüntüler -Althusser'in de belirttiği- devletin ideolojik

\footnotetext{
${ }^{4}$ Apple firması tarafından geliştirilen ve internet aracılığıyla görüntülü konuşmaya yarayan bir uygulama.
} 
aygitlarından biri olan dinin / dini kurumların toplumsal işlevinin doğrudan görünür hale gelmesi bakımından dikkat çekici bir örnektir.

Darbe girişiminin gerçekleştiği gece ilerleyen saatlerde direniş güçlenmiş ve bunun karşılığında darbeciler de saldırılarının şiddetini arttırarak Türkiye Büyük Millet Meclisi'ni (TBMM) bombalamışlardır. Belgeselde meclisin bombalanması hem dışarıdan, hem de milletvekilleri tarafından çekilen amatör videolar vasıtasıyla içeriden gösterilmiştir. Kurtuluş Savaşı sırasında dahi bombalanmayan, cumhuriyetin ve demokrasinin sembolü olan TBMM'nin savaş uçakları ve helikopterler tarafindan bombalanma görüntüleri; bu dehşet verici olayı gelecek kuşakların hatırlamasını amaçlayarak, bu tür girişimlerin doğrudan milletin iradesine ve bağımsızlı̆̆ını karşı gerçekleştiğini vurgulamaktadır. Dolayısıyla belgeselin hedeflediği farkındalık yaratma amacının en net ortaya çıktığ kısımdır. Çünkü bu saldırı; o an orada bulunan Türkiye Büyük Millet Meclisi'nin içindeki vekilleri ve görevlileri olduğu kadar, milletin kararlarını ve tercihlerini de hedef almaktadır. $\mathrm{Bu}$ nedenle görüntülerin gösterdiği şiddet ve dehşet anları dışında yukarıda sözü edilen sembolik yönünün unutulmaması, milletin ortak hafizasında yer etmesi amacıyla kullanıldığı anlaşılmıştır.

Ardından Cumhurbaşkanı Recep Tayyip Erdoğan'ın İstanbul'a gelişi ve hava alanında yaptığı basın toplantısı görüntülerinin yer verilmiştir. Cumhurbaşkanı Erdoğan, Türkiye Cumhuriyeti'nin kurucusu Mustafa Kemal Atatürk'ün bir fotoğrafının önünde basın toplantısı yapmaktadır. Bu noktadan hareketle, belgeselde cami, bayrak ve ülkenin kurucusunun görüntülerine yer verilerek; Türkiye'deki hakim siyasal ideolojilerin, tarihsel kültürel ve sosyolojik bağların bu girişime gösterdiği direnişin de ortak olduğu vurgulanmıştır. Daha sonra darbecilerin Cumhurbaşkanı Erdoğan'ın Facetime uygulaması vasıtasıyla canlı olarak bağlandığı CNN-TÜRK televizyonunu ele geçirme girişimi ve darbecilerin halk ve güvenlik güçleri tarafından engellendikleri görüntüler ekrana gelmiştir. Burada vurgulanmak istenen ise, halkın bağımsızlığına, iradesine ve seçimlerine sahip çıktığı gibi, haber alma kaynağına da (medya) sahip çıkmasıdır. Bunun yanı sıra olaylar hakkında geniş kitlelere bilgi aktarımını sağlayan, ayrıca yetkililerin mesajlarının da halka doğrudan aktarılmasını gerçekleştiren ve bu yönüyle de darbecilere direniş gösteren medyayı desteklemesidir.

Darbe girişiminde bulunan askerlerin yakalanma, kullandıkları araçların ise çekilme görüntüleri verilmiş, devamında yine yeni bir girişimimde bulunulmaması için konvoy halinde askeri birliklerin giriş çıkışlarını kapatmaya giden iş makinelerinin görüntüleri kullanılmıştır. Belgeselin başında sokaklara çıkan askeri araçların siviller tarafından kaldırılması, halkın vergileriyle alınan bu araç ve gereçlerin kendisine karşı kullanılmasına gösterdiği bir tepkidir. Dolayısıyla bu araçların asıl sahibi konumundaki halk, kendisinin rızası / onayı olmadan kullanılmasını da engellemiştir. Bu görüntü aynı zamanda ülkenin sahibinin herhangi bir zümre, sınıf veya grubun değil halkın kendisinin olduğunu da vurgulamaktadır.

Belgeselde daha sonra darbe girişiminin başarısız olması sonucunda ortaya çıkan tablo, darbecilerin yakalanma görüntüleri eşliğinde verilmiş, ardından Başbakan Binali Yıldırım, İçişleri Bakanı Efkan Ala, Milli Savunma Bakanı Fikri Işık, Adalet Bakanı Bekir Bozdağ ve darbenin başlangıcında darbeciler tarafindan rehin alınan, sonrasında ise başarılı bir operasyonla kurtarılan Genelkurmay Başkanı
Org. Hulusi Akar'ın Başbakanlık Konutu'nda düzenledikleri basın toplantısı görüntüleri aktarılmıştır. Bu görüntü devletin ve hükümetin güvenlik birimlerinin başındaki yöneticilerin bir arada olması ve bu girişimi tamamen engellediklerini sonucunu vermektedir. İlgili sorumlular görevlerinin başında kalmış ve kapısında iki subayın nöbet tuttuğu Başbakanlık Konutu'nun giriş merdivenlerinde, arka planda Türk bayrakları olduğu halde topluca bir açıklama yaparak seçilmiş iktidarın halkın iradesine ve bağımsızlığına sahip çıktığı mesajını vermişlerdir.

Belgeselin sonunda yine Başbakan Binali Yıldırım'ın mecliste milletvekillerine yaptığ $\breve{1}_{1}$ konuşma, sonrasında muhalefet partilerinin liderleri Cumhuriyet Halk Partisi (CHP) Genel Başkanı Kemal Kılıçdaroğlu hem Milliyetçi Hareket Partisi (MHP) Genel Başkanı Devlet Bahçeli'nin yine Türk bayrağı önünde, darbe girişimine karşı olan konuşmalarının görüntülerine yer verilmiştir. $\mathrm{Bu}$ durum yukarıda da belirtildiği gibi Türkiye'deki hakim siyasal ideolojilerin seçilmiş siyasal temsilcilerinin doğrudan bu girişime ilişkin tavırlarını da vurgulamaktadır.

Belgeselin sonunda bayrakları ile meydanları dolduran, tankların altına yatan, silahlı darbecilere direnen halkın görüntülerine yer verilmiş ve en sonunda bir video geçiş efektiyle dalgalanan bir Türk Bayrağı görseline geçiş yapılmıştır. Burada verilmek istenen mesaj ise Türkiye halkının geçmişte olduğu gibi günümüzde de bağımsızlığına ve iradesine baskı konulmasına razı gelmeyeceğini, bunu açıkça bir vatan ve bekâ sorunu olarak gördüğünü, bu gibi durumlarda ideolojik ve toplumsal farkl1lıkları bir yana bırakıp, bağımsızlık için bir araya geleceği mesajıdır.

Belgeselin genelinde kullanılan görüntülerin çoğu güvenlik kameralarından, video kaydetme özelliği de olan akıllı telefonlar ile amatör kamera kayıtlarından oluşmaktadır. Bu yönüyle bakıldığında, spontane bir biçimde aynı anda, birçok yerde gerçekleşen ve çok kişi tarafindan şahit olunan bu tür toplumsal olayların kayıt altına alınması; tanıklık edilen olayın aynı zamanda bir parçası haline gelindiğinin de bir göstergesidir. Bu tarz görüntülerin, Widgington'un da gerçek olaylar aracılığıyla, gerçek kişileri takip ederek, gerçekliğin bir parçasını yakalamaya çalışan belgeseller olmadığını vurgulayarak, aktivist video olarak tanımladığı türde görüntüler olduğunu söylemek mümkündür. (Widgington, 2015, s. 118) Fakat bu ve benzeri görüntülerin vatandaşlar veya sivil toplum kuruluşları tarafından derlenerek, bir araya getirilmesi ve bir anlatı formuna (belgesel, film, haber vb.) dönüştürülmesi, sonrasında da zaman ve mekan sınırlaması olmadan, internet üzerinden kolaylıkla ulaşılabilecek bir platformda saklanması, dijital aktivizmin farkındalık yaratma eylem türüne önemli bir örnek teşkil etmektedir. 


\section{The Revolution Will Not Be Televised Belgeselinin Göstergebilimsel Analizi}

Tablo 3. The Revolution Will Not Be Televised adl belgeselin künyesi

\begin{tabular}{|c|c|}
\hline Başlık & $\begin{array}{l}\text { The Revolution Will Not Be Televised - Chavez: } \\
\text { Inside the Coup }\end{array}$ \\
\hline $\begin{array}{l}\text { Kullanic1 } \\
\text { Adı }\end{array}$ & Andy Goodall \\
\hline Url & $\begin{array}{l}\text { https://www.youtube.com/watch?v=FEsSf7ARpw } \\
8 \& \mathrm{t}=268 \mathrm{~s}\end{array}$ \\
\hline Süre & 01 sa. $15 \mathrm{dk} .11 \mathrm{sn}$ \\
\hline $\begin{array}{l}\text { Yüklenme } \\
\text { Tarihi }\end{array}$ & 18 Şubat 2014 \\
\hline $\begin{array}{l}\text { Görüntülen } \\
\text { me Sayı1s1 }\end{array}$ & 223450 \\
\hline $\begin{array}{l}\text { Beğenme } \\
\text { Sayıs1 }\end{array}$ & 226 \\
\hline $\begin{array}{l}\text { Beğenmem } \\
\text { e Sayıs1 }\end{array}$ & 4 \\
\hline $\begin{array}{l}\text { Yorum } \\
\text { Say1s1 }\end{array}$ & 29 \\
\hline Etiketler & Yok \\
\hline Tanım & $\begin{array}{l}\text { The revolution will not be televised directed and } \\
\text { photographed by Kim Bartley and Donnacha } \\
\text { O'briain Ireland, } 200374 \text { minutes in Spanish with } \\
\text { English subtitles Hugo Chavez elected president of } \\
\text { venezuela in 1998, is a colorful, unpredictable folk } \\
\text { hero, beloved by his nation's working class and a } \\
\text { tough-as-nails, quixotic opponent to the power } \\
\text { structure that would see him deposed. Two } \\
\text { independent filmmakers were inside the } \\
\text { presidential palace on April 11, 2002, when he was } \\
\text { forcibly removed from office. They were also } \\
\text { present } 48 \text { hours later when, remarkably, he } \\
\text { returned to power amid cheering aides. Their film } \\
\text { records what was probably history's shortest-lived } \\
\text { coup d'état. It's a unique document about political } \\
\text { muscle and an extraordinary portrait of the man } \\
\text { The Wall Street Journal credits with making } \\
\text { Venezuela "Washington,s biggest Latin American } \\
\text { headache after the old standby, Cuba." }\end{array}$ \\
\hline
\end{tabular}

Bir devlet başkanının portresini hazırlama amacıyla çekimlerine başlanan belgesel, daha sonra tesadüf eseri olarak gerçekleşen bir darbe teşebbüsünü anbean görüntüleme şansına kavuşmuştur. Bununla birlikte belgeselde ortaya çıkan, seçilen görüntüler ideolojik bakımdan vurgulanan yaklaşımı da göstermektedir. Bu bağlamda ortaya çıkan görsel analiz tablosu aşağıdadır.

\begin{tabular}{|c|c|c|}
\hline Gösterge & Gösteren & Gösterilen \\
\hline ABD Bayrağ1 & $\begin{array}{l}\text { Yıldızlar, düz } \\
\text { çizgiler, Mavi, beyaz } \\
\text { kırmızı renkler }\end{array}$ & Emperyalizm \\
\hline Petrol Rafinerisi & Endüstriyel Bina & $\begin{array}{lr}\text { Doğal, } & \text { kaynak } \\
\text { Olayların } & \text { asıl } \\
\text { nedeni } & \end{array}$ \\
\hline $\begin{array}{l}\text { Chavez - Nöbetçi } \\
\text { Asker sohbeti }\end{array}$ & Başkan / İnsan & $\begin{array}{l}\text { Sevgi, } \\
\text { ilişkisi }\end{array}$ \\
\hline Simone Bolivar & Tablo & Bağımsızlık \\
\hline Venezuela Bayrağ1 & $\begin{array}{l}\text { Sar1, Mavi Kırmızı } \\
\text { renkler, y1ldızlar ve } \\
\text { hanedan arması }\end{array}$ & Ulusal birlik \\
\hline İncil & Kitap & Dindaşlık \\
\hline $\begin{array}{l}\text { Chavez'in } \quad \text { sol } \\
\text { yumruğu }\end{array}$ & İnsan uzvu & Sosyalizm \\
\hline
\end{tabular}

Belgeselin en başında ellerinde Venezuela bayrakları olduğu halde yoksul görünümlü fakat neşeli ve coşkulu bir biçimde şarkılar söyleyen halkın Chavez'e sevgi gösterilerinde bulunması gösterilmiştir. Buradaki görüntülerde hem halkın elinde taşıdığı Venezuela bayrakları, hem de Chavez'in bayrağın renklerini taşıyan giysileri dikkat çekmektedir. Bayrak bir bağımsızlık sembolü olduğu kadar, Chavez'in iktidara gelmesinde oluşturduğu ve ülkenin Bolivarcı köklerine yaptığı bir gönderme haline gelmiştir. Aynı zamanda Chavez'in görüntülerde bordo bir askeri bere ile gösterilmesi, onun askeri geçmişine de bir gönderme yapmakta ve gerektiğinde yeniden ülkesini savunmak için askeri tedbirleri almaktan çekinmeyeceğini vurgulamaktadır. Bunun yanı sıra belgeselin en başında küçük gruplarla başlayan, ardından Chavez'i bir aracın üzerinde ve etrafı giderek kalabalıklaşan, nihayetinde binlerce insanın yer aldığı bir mitinge gelişini gösteren prolog kısmi; hem onun yoksul kitlelerle olan yakın ilişkisini, hem de halkın içinden çıkarak iktidara gelme sürecini anlatmaktadır.

Ardından ekranda 11 Nisan 2002 yazı gözükür. Amerikan aksanlı bir haber spikerinin Chavez'e yapılan darbe haberini sunduğu gösterilmektedir. Aynı zamanda Chavez'in belgeselin giriș kısmında yaptığı konuşmada kastettiği düşmanların kim olduğuna yönelik ilk ima budur. Ekran kararır ve bu yeni dönemde ABD'nin Venezuela'da ki petrol üzerinden istikrar sağlama umudunu doğduğu söylenir. Bu esnada ekranda petrol üretim tesisleri görülmektedir bu durum ülkenin doğal zenginliklerine ve ABD'nin Venezuela'ya olan ilgisinin nedenine gönderme yapmaktadır. Ekran tekrar kararır, böylelikle darbe sürecine giden olayların başlangıcı ve asıl nedeni hakkında izleyici bilgilendirilmiştir.

Ekran yeniden açıldığında film ekibi Chavez hakkında bir belgesel yapmak için Venezuela'da olduklarının bilgisini verir ve onun günlük çalışmalarından, yakın çevresiyle olan diyaloglarından kesitler verilir. Görüntülerde Chavez güler yüzlü, jest ve mimiklerini sıkça kullanılan, insanlarla konuşurken onlara dokunan, sıcakkanlı bir lider olarak 
yansıtılmıştır. $\mathrm{Bu}$ da Chavez'in olumlu bir portre olarak sunulmasına hizmet etmektedir.

Daha sonra onun asker üniformasıyla halkın arasındaki görüntüleri ekrana verilmiştir. Görüntülerde giyimlerinden yoksul oldukları anlaşılan Venezuela halkı kendisine yoğun sevgi gösterisinde bulunmakta, fotoğraf çektirmekte, onunla şarkı söylemekte ve isteklerini içeren not kağıtlarını iletmektedir. Bu görüntülerde Chavez'in halkla kurduğu güçlü iletişim dikkat çekicidir. Kendisini görmeye gelen, onunla konuşan Venezuelalıların gözlerindeki sevgi ve umut onun adeta bir kurtarıc1, bir kahraman gibi görülmesinin ve darbe girişiminin ardından yine onun hakkını savunmak için sokaklara çıkmasının ipuçlarını vermektedir. Kendisini görmeye gelen halkın elinde ayrıca Che Guevara posterleri ve devrimci sloganların olduğu pankartlar bulunmaktadır. Bu da Chavez'in halkı ideolojik açıdan da örgütlediği / bilinçlendirdiğini göstermektedir. Ardından Chavez'in bu amaçla devlet televizyonu olan Kanal 8'de gerçekleştirdiği "Alo Başkan" adlı programdan kesitler verilmiştir. Burada da Chavez'in halkla olan iletişim kanallarının hem yüz yüze, hem de geleneksel medya aracılığıyla devam ettirmeye çalıştı̆̆ 1 ve buna özel önem verdiği görülmektedir. Ne var ki ülkede muhaliflerin elinde bulunan diğer medya kuruluşları Chavez'in halka yönelik bu çalışmalarına yer vermemekte ve karşıt bir yayın politikası izlemektedir. Bu açıdan söz konusu görüntüler Chavez'in bir devlet başkanı olarak ülkesinin medyası tarafından yalnız bırakıldığını göstermektedir.

Belgeselde daha sonraki görüntülerde Chavez'in helikopterle başkanlık Sarayına gelişi verilir. Burada Chavez, kendisini karşılamada görevli olan bir saray muhafızı ile sevecen biçimde konuşmaktadır. Görüntülerde darbe gerçekleştikten sonra halkla birlikte Başkanlık Sarayı'nın tekrar ele geçirilmesinde etkin rolü bulunan saray muhafizlarının Chavez'e duydukları sevgi ve bağlılığın nedenlerine gönderme yapılmaktadır. $\mathrm{Bu}$ görüntülerin sonrasında başkanlık sarayı çalışanlarının röportajları gelmektedir. Halktan gelen talepleri inceleyen çalışanlar, bunları uygun biçimde arşivlemektedirler. Raflar ve dosyaları dolusu olduğu görülen bu taleplerin çoğunda iş, ekonomik yardım vb. konular mevcuttur. Bu durum aslında doğal kaynaklar bakımından zengin bir ülke olan Venezuela'nın gelir dağılımındaki eşitsizliği ve halkın çoğunluğunun yoksul ve yardıma muhtaç olduğunu göstermektedir.

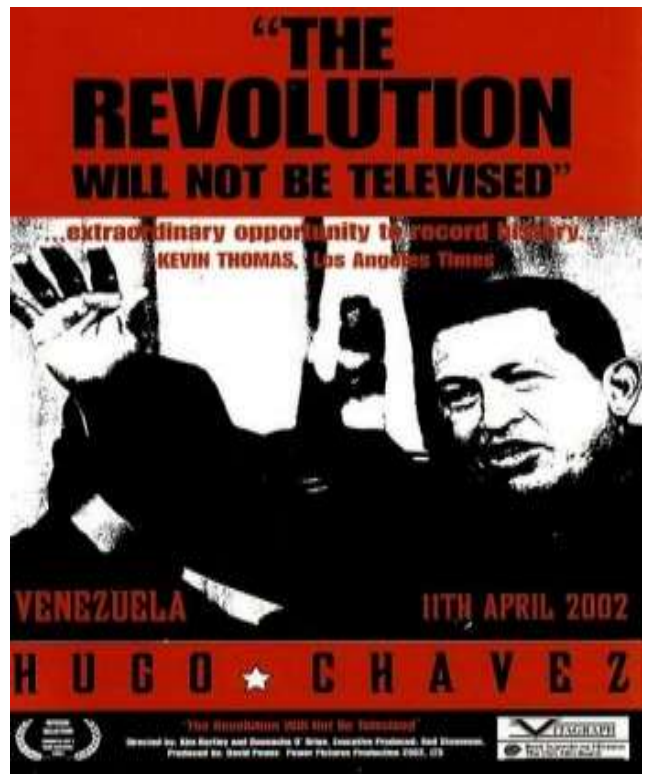

Görsel.3) "The Revolution Will Not Be Televised" Belgeselinin Afişi

$\mathrm{Bu}$ görüntülerin akabinde Chavez çalışma arkadaşları ile bir toplantı esnasında gösterilir. Burada iktidar olarak kendilerinin medyayı kullanmaktaki yetersizliğinden bahsederek, medya üzerinden halkla iletişim kuramadiklarını ve başarılı çalışmalarını duyuramadıklarını söylemektedir. Buna karşın medyada kendilerinin başarısız olarak yansıtıldığını da belirtmektedir. Devaminda ise Chavez'in bu sözlerini doğrularcasına Venezuela özel televizyonlarının Chavez karşıtı yayınlarından kesitler verilmiştir. $\mathrm{Bu}$ yayınlar açık oturum veya haber biçiminde ciddi programlardır fakat Chavez'i cinsel takıntıl1, akli dengesi yerinde olmayan biri gibi göstermekte ve çok yakında Chavez'siz bir döneme geçileceğini belirterek, üstü kapalı biçimde darbe iması yapmaktadır. Söz konusu yayınların ve haberlerin bir hiciv ya da eğlence programında değil de, ciddi konuların tartışıldığ programlarda gerçekleşmesi, Chavez'in halk nezdinde itibarsızlaştırılması, halkın darbeye psikolojik olarak hazırlanmasını sağlamaktadır.

Daha sonra Chavez'in 11 Eylül 2001'de New York'ta gerçekleşen terör saldırılarından sonra devlet televizyonunda yaptığ1 konuşma gösterilmektedir. Chavez burada Latin Amerika ülkelerini sömürgecilikten kurtaran ve özgürleştiren Simone Bolivar'ın üniforma içinde resmedildiği bir tablonun önünde, Afganistan'da ABD öncülüğündeki askeri güçlerin gerçekleştirdiği saldırı sonucu hayatını kaybeden çocukların fotoğraflarını göstererek terörle ve terörizmle mücadele politikalarının yanlış olduğunu söylemektedir. Bu görüntüler düz anlamsal boyutta ele alındığında Chavez'in dünya barışına katkı sağlamak amacıyla ülkesinin kurucu liderine tablosu önünde kamuoyuna yaptığı bir konuşma olarak değerlendirmek mümkündür. Yan anlamsal olarak bakıldığında ise Chavez'in Venezuela Bayrağı ve SimoneBolivar tablosunun önünde yani önemli iki ulusal bağımsızlık sembolünü arkasına alarak, elindeki katliam fotoğraflarıyla bu eylemlerin yanlışlığını dile getirmesi; onun ABD öncülüğündeki batılı kapitalist devletlerin oluşturduğu askeri koalisyona, onların siyasal, ekonomik ve kültürel hegemonyasına karşı ideolojik bir karşı çıkışının da yansimasidir. 
Chavez'in bu konuşmasının hemen ardından Venezuela özel kanallarında ABD Dışişleri Bakanı Colin Powell'ın ve diğer yetkililerin bu açıklamalara ilişkin kaygılarını ve karşı suçlamalarını dile getirdiği konuşmaların haberleri verilmektedir. Böylelikle kendi ülkesindeki özel kanallarını muhalefet etmek için onun ideolojik ekonomik ve kültürel olarak hasmı konumundaki ABDli yetkililerin açıklamalarına yer vermesi; yine darbeye giden süreçte Chavez'in içeride baskıcı olduğu kadar, küresel ölçekte de teröre destek veren bir lider gibi yansıtılmasına yardımcı olmuştur.

Daha sonra belgeselde Chavez'in Başkanlık Sarayı'nda bir çocukluk anısını anlattığ 1 bölüm gösterilmiştir. Chavez anlatırken Başkanlık Sarayı'ndan ve çalışma odasından çeşitli detaylar gösterilir. Görüntüler gece çekilmiştir, sarayın bahçesi, koridorları boştur. $\mathrm{Bu}$ durum güçlü, halkla kolay iletişim kuran Chavez'in yönetimde ise yalnız olduğunu vurgulamaktadir.

Çocukluk anısında büyükannesinin dedesi için "katil" dediğini anlatan Chavez, aslında onun ailesinin şerefini kurtarmak için bunu yaptığını ve daha sonra devrimcilerin saflarına katıldığını anlatır. Bu esnada duvardaki Simon Bolivar portresi gösterilir. Chavez'in Venezuela'ya bağımsızlığını kazandıran Bolivar ve onun açtığı devrim yolunda savaşa katılan dedesi hakkında anlattığı bu anı ile birlikte onun bağımsızlık düşüncesinin geçmișten gelen güçlü bir yönü olduğuna vurgu yapılmaktadır. Ayrıca çalışma odasındaki detaylardan birinde İncil de gösterilmektedir. $\mathrm{Bu}$ da onun İncil'in temel öğretilerinde ${ }^{5}$ yer aldığı gibi yoksullarla kişisel olarak ilgilenen, onların yaşadığı sıkıntıları bertaraf etmeye çalışan ve onlarla yardımlaşmanın bir gereklilik olduğuna inanmış bir kişi olduğunu ima etmektedir.

Daha sonra Venezuela'nın başkenti Caracas'ın kenar mahallelerinde oturan Chavez taraftarlariyla yapilan röportajlara yer verilmiştir. Görüntülerde gündüz vakti, çarpık yapılaşmış ve çoğu bakımsız, virane haldeki yoksul mahalleri genel planda gösterilir, sonrasında Chavez taraftarlarıyla yapılan röportajlarda da bu görüntüler arka planlarda görülmektedir. Konuşanlardan biri gelir dağılımındaki bozukluktan söz ederek, "bir grup çok zengin" ifadesini kullandığında ekranda Caracas'ın gökdelenleri ve gelişmiş muhitleri gösterilmektedir.

Öte yandan Chavez karşıtlarının röportajlarına geçildiğinde ise gece, büyükçe bir villanın içinde toplanan insanların görüntülerine yer verilmiştir. Muhalifler, -Chavez taraftarlarının aksine- daha bakımlı ve şı giyimlidir. Protestolarında gece sokaklarda tencere, tava çalmakta ve gösterilere pahalı otomobillerle katılmaktadırlar. Ellerindeki pankartlarda Titanic $^{6}$ filminin afişine gönderme yapılarak Küba Devlet Başkanı Fidel Castro ile Chavez'i hicveden veya terörist El-Kaide örgütünün lideri Usame Bin Ladin ile birlikte oturuyormuş gibi montajlandığı görseller taşımaktadırlar.

Belgeselin yukarıdaki kısmına bakıldığında, Chavez karakterinin ve politikalarının Venezuela toplumunda derin bir kutuplaşma yarattığı anlaşılmaktadır. Yoksul halk kentin dağlık kesimlerinde, kötü yaşam koşulları içinde olsa bile geleceğe dair bir umut içindedir. Yüksek gelirli kesim ise imtiyazlarını kaybetme korkusu içindedir ve bu nedenle yoksullara karşı şüpheci, olumsuz tavırlar içindedir. Bu nedenle ev işlerinde yardımcı olan çalıșanlardan dahi şüphe duyulması, güvenilmemesi gerektiği toplantılarında özellikle vurgulanmaktadır. Söylemlerde görülen bu karşıtlık, görsel bakımdan da aynı şekilde vurgulanmıştır. Yoksulların röportajları ve eylemleri, gündüz vakti, sokaklarda, müzik aletleri ve şarkılar eşliğinde, ahenk içinde gösterilirken, zengin kesimin eylemleri ise gece vakti karanlıkta, toplantıların kapalı mekanda yapıldığı, eylemlerde tencere tava çalınarak bir gürültü ve kakafoni ortamı içinde, öfkeli, hırçın bir biçimde gösterilmiştir.

Bu bağlamda ele alındığında, belgeselde var olan gün 1şığg ve gece karşıtlığını, yaşam / ölüm, umut / sıkıntı, güven verici / kaygılandırıcı vb. çeşitli farklı okumalarla anlamlandırmak mümkündür. Yücel'in de (2013, s. 163) belirttiği gibi, karanlık bir görsel alan ile birleştirilen gösterilenler geceyle, korkuyla, anlaşılamayanla özdeştirilebilirken, aydınlatılan bir görsel alan akıl, bilgi, bilgelik veya kutsal 1şı̆̆ın gücü ve her yerde olması gibi kavramlarla özdeşleştirilebilir. Belgeselin dramatik yapısı içinde yer bulan bu durum, karşıt ideolojilerin güç mücadelesi içinde sıkça görülmektedir.

Bununla birlikte ülkedeki özel televizyonların, Chavez'i küçük düşüren ve Chavez taraftarlarını Mussolini ve Hitler'in çetelerine benzeten haber ve yorumlarda bulunarak, ülke içindeki grupları daha da kutuplaştıran bir yayın politikası izlediği gösterilmektedir. Muhalefet liderleri Pedro Carmona ve Carlos Ortega'nın ABD'ye giderek orada gerçekleştirdiği temaslarla birlikte istihbarat ve dişişleri bakanlığı yetkililerinin açıklamalarına yer verilmiştir. Görüntülerde yalnızca ABD'li yetkililer vardır ve görüşlerini bir meclis / komisyon toplantısında aktarmaktadirlar. $\mathrm{Bu}$ durum, Venezuela'nın iç işlerine müdahale için yapılacak hamlelerin önceden belirlendiği ve ülkedeki diğer kesimlerin görüşlerinin alınmadığını göstermektedir.

Akabinde yine özel televizyonlarda Venezuela ordusundan bir generalin yaptığı açıklamaya yer verilmiştir. General üzerinde üniforması olduğu halde düz bir arka planda tek başına Chavez'i görevi bırakmaya davet etmekte, şayet direnirse bunun zorla gerçekleşeceğini belirtmektedir. Görüntü incelendiğinde generalin açıklamayı yaptı̆̆ olmamakta, kendisin bu açıklamayı hangi ideolojik veya toplumsal saikle yaptığını gösterebilecek herhangi bir sembol veya nesne bulunmamaktadır. Yalnızca üniforması üzerindedir fakat yanında herhangi bir rütbeli asker mevcut değildir. Bu nedenle generalin böyle bir konuşma yapmasının ardındaki gücün devlet içinden değil devlet ve ülke dışından bazı odaklar olduğu anlaşılmaktadır.

Daha sonra Pedro Carmona'nın basın toplantısı ekrana getirilir. Carmona toplantıda muhalefete protesto ve yürüyüş çağrısı yapmaktadır. Chavez'in gerçekleştirdiği miting ve toplantıların aksine, Carmona'nın önünde onlarca televizyon kanalının mikrofonu vardır, etrafı basın mensupları ile çevrilmiştir. Bu durum, medyanın muhalefetin açıklamalarına daha fazla yer verdiği ve onların amaçları doğrultusunda kullanıldığının da bir göstergesidir.

Carmona'nın çağrısının ardından muhalifler yürüyüşü başlatmışlardır. Diğer yandan Chavez taraftarları ise desteklerini göstermek amacıyla Başkanlık Sarayı çevresinde toplanmışlardır. Muhaliflerin gerçekleştirdikleri protestolarda 
Venezuela Bayrağı ve çeșitli pankartların yanı sıra Amerikan bayrakları da görülmektedir.

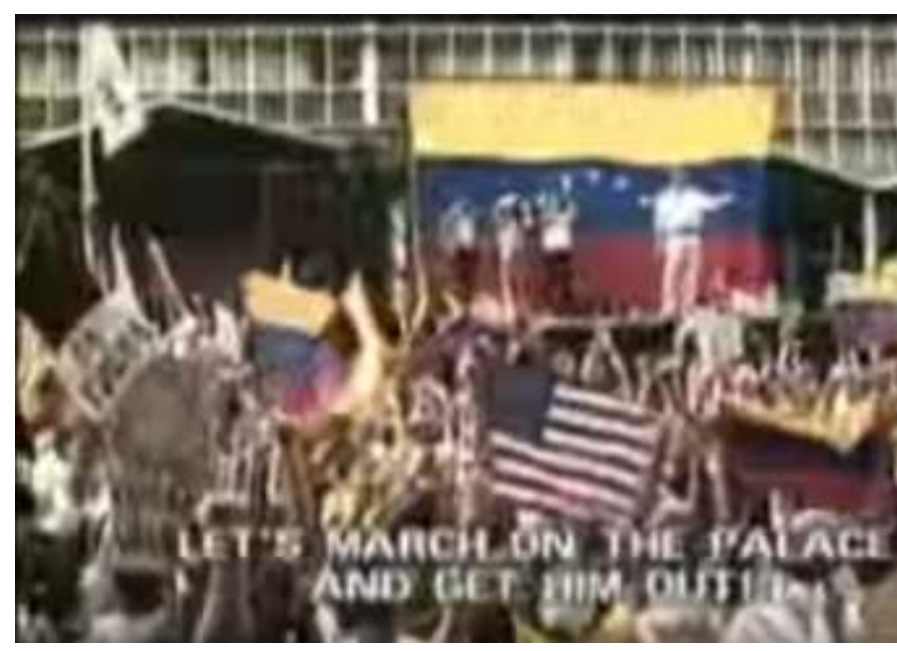

Görsel.4) The Revolution Will Not Be Televised belgeselinden bir kare

Diğer yandan Chavez taraftarlarının ellerinde de Venezuela bayrakları mevcuttur, bunun yanı sıra Chavez fotoğrafları ve ülkenin emperyalizme karşı bağımsızlığının kazanılmasını sağlayan SimonBolivar'ın resimlerini taşımaktadırlar.

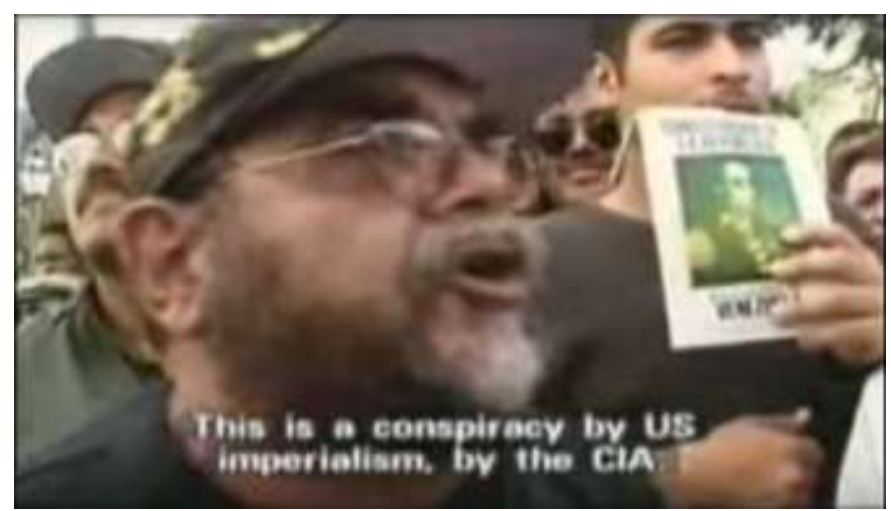

Görsel.5) The Revolution Will Not Be Televised Belgeselinden bir kare

Bu görüntülerden hareketle; belgeselde Chavez taraftarlarının bu eylemlerin arkasında emperyalist dış güçlerin olduğunu ve Chavez'i desteklemenin aynı zamanda bağımsızlığı da korumak anlamına geldiğini bildikleri vurgulanmaktadır. Nitekim Başkanlık Sarayı önündeki Chavez taraftarları bu durumu belgeselde verilen röportajlarda da ifade etmekte ve medyayı da bu planın içinde olmakla suçlamaktadırlar.

Ekrana gelen muhaliflerin taşkınlık görüntülerinde, bazı kişilerin sokakları yakıp yıktıkları, çevreye zarar verdikleri görülmektedir. Bazı protestocuların ise Venezuela askerlerine sarf ettikleri "Def olun Küba'ya gidin, Castro'nun yanına" sözleri verilmiştir. Bu sırada Başkanlık Sarayı önünde nöbet tutan bir askerin görüntüsü ekrana gelir. Silahına sıkıca sarılan asker, oldukça gergin ve ne yapacağını bilmez bir haldedir. Askerin bu durumu Venezuela güvenlik güçlerinin, yaşananlar karşısındaki kararsız halini de göstermektedir.

İki taraf birbirine yaklaşırken kimliği belirsiz kişilerin çatılardan kalabalığın üzerine ateş açtığg görülür. Halk korku ve panikle kaçışmaya başlar. Bu sırada Chavez taraftarlarından silahlı olanlar da silah seslerinin geldiği yöne doğru ateş etmeye başlarlar, aynı zamanda muhalefete yakın bir televizyon kanalı bu anların görüntülerini çekmektedir. Daha sonra o dönemde özel kanalların birinde editörlük yapan bir gazetecinin bu olayla ilgili röportajı ekrana getirilir. Gazeteci, görüntülerde manipülasyon yapılarak, medyanın Chavez taraftarlarının muhaliflerin üzerine ateş açtığı algısı oluşturmaya çalıştı̆̆ını ifade eder.

Kızgın halk grupları, polis ve askerin müdahalesi, halkın üzerine kimliği belirsiz kişilerce ateş açılması, sonrasında ölen yaralanan insanlar, panikle kaçışanlar vb. görüntüler darbeye giden sürecin olgunlaşmasını ve meşrulaşmasını sağlamak için ihtiyaç duyulan toplumsal olayların gerçekleştiği anlardır. Bununla birlikte, görüntülerde yer alan ve -Althusser'in ifadesiyle- devletin baskı aygitlarını temsil eden asker ve polislerin, bu tür kaos zamanlarında takındıkları tutumun, iktidar için belirleyici olduğu görülmektedir. Zira, genel toplumsal rızanın ortadan kalktığı, kaos ve düzensizliğin ortaya çıktığı anlarda, baskı gücü otoriteyi sağlamak adına yasal olsun ya da olmasın- gerekli önlemleri almaktadır.

Tüm bu kargaşa görüntülerinin ardından muhalefet lideri Pedro Carmona'nın özel televizyonlardaki açıklamasına yer verilmiştir. Carmona düz siyah bir fonun önünde, yaşananlardan Chavez'i sorumlu tutmakta ve bir an önce istifa etmesini istemektedir. Eski Devlet Petrol Şirketi Direktörü ise, yine siyah bir fonun önünde ve ekranın diğer bölümünde yaşanan kaosun görüntüleri oynatılırken, askerleri yönetime el koymaya çağırmaktadır. Ardından Venezuela Deniz Kuvvetleri komutanı yanında 9 üst rütbeli subayla birlikte gri bir fonun önünde Chavez'e verdikleri desteği geri çektiklerini açıklamaktadır.

Söz konusu tüm açıklamalarda, daha önce Chavez'in görevini bırakmasını isteyen generalin görüntülerinde olduğu gibi bu açıklamayı hangi ideolojik ya da toplumsal gerekçeye dayandırdıklarını simgeleyecek herhangi bir nesne bulunmamaktadır. Fondaki siyah renk; 1şı̆̆ın olmaması, hiçliği, cehaleti, melankoli ve karanlık düşünceleri çağrıştıran anlamlara sahip bir renktir. Psikolojik düzlemde ele alındığında ise, terk edilme korkusunu, umutsuzluğu, yaşamdan korkmayı çağrıştıran, nadiren farklı anlamlar için kullanılsa da çoğunlukla negatif düşünce ve duyguları yansıtmaktadır. (Yücel, 2013) Belgesel bağlamında değerlendirildiğinde, muhaliflerle ilgili çoğu görüntüde ortaya çıkan (gece, karanlık, siyah fon vb) imgelerle Chavez karşıtlarını olumsuz gösteren ve dolayısıyla taraflı bir bakış açısına sahip olunduğu anlaşılmaktadır.

Bunlar yaşanırken Chavez'in Başkanlık Sarayı önündeki askerlerin görüntüleri ekrana getirilir. Telaşlı bir biçimde beklemektedirler. Chavez ise içeride bakanlarla toplantı yapmaktadır. Başkanlık Ofisi çalışanları da olayların aslını halka duyurabilmek için çaba sarf etmektedirler. Fakat bazı askeri birliklerin devlet televizyonuna el koyduğu haberleri gelmektedir. Gece saat 21:30'da başlayan başkanlık sarayı önünden bir canlı yayın yapmak isterler fakat darbeciler hemen yayını keserler. Gece ve karanlık, artık Chavez taraftarların içinde bulunduğu durumu ve darbecilerin medya vasıtasıyla uyguladıkları karartmayı gösteren bir simge olmuştur.

Daha sonra gergin ve endişeli başkanlık ofisi çalışanları ekrana getirilir ve bir grup asker Chavez'i tutuklamaya gelir. Chavez götürülürken hükümet yetkilileri bunun bir darbe olduğunu söylemekte ve halkın buna sessiz kalmayacağını ileri sürmektedirler. Başkanlık ofisi çalışanlarının sevgi gösterileri 
arasında Chavez bir arabaya bindirilerek, götürülür. Sabaha karşı yeniden basın mensuplarının karşısına geçen Pedro Carmona'nın yanında bu sefer Venezuela ordusunun üst rütbeli subayları bulunmaktadır. Söz konusu görüntüler, siyasi bir gücün bertaraf olurken yerine yeni bir gücün gelişini göstermektedir. Fakat buradaki asıl gösterilen, ordunun yani baskı aygıtının desteği ve iş birliğinin elde edilmesidir. Böylelikle kimin iktidara sahip olacağı da belli olacaktır.

Sabah olduğunda Başkanlık Sarayı'nda her yer kalabalıktır ve herkes birbirini tebrik etmektedir. Kutlama için saraya gelenler arasında ülkenin dini liderleri de vardır. Darbecilerin göreve getirdiği yeni Başkan Carmona'nın yemin töreninde daha önceden Chavez'e istifa çağrısı yapan generaller ile Venezuela Deniz Kuvvetleri Komutanı da görülmektedir. Başkanlık yeminini eden Carmona, salondakiler tarafindan coşkulu bir biçimde alkışlanır. Burada dikkati çeken asıl detay ise, halk oyuyla gelmeyen ve darbeciler tarafindan göreve getirilen Carmona'nın başkanlık yeminini de halkın önünde değil, kendisini göreve getiren bir azınlı̆̆ın önünde, bir salonda etmesidir. Bu görüntüler aslında darbecilerin dar bir çıkar çevresi olduğunun ve manipülasyonlarla harekete geçirdikleri kendi taraftarlarının bile resmi onayını almadan, bir emrivaki yaparak iktidarı ele geçirmeye çalıştıklarının göstergesidir.

Nitekim bu durum -belgeselde de gösterildiği gibi- hemen vatandaşların tepkisini çekmiş ve sokaklarda eylemler başlamıştır. $\mathrm{Bu}$ eylemlere darbeci hükümetin tepkisi de şiddetli olmuş, ölüm ve yaralanma olayları meydana gelmiştir. Gösteri ve çatışmalar giderek artmış ve Chavez taraftarları yine ellerinde Venezuela bayrakları ve Chavez posterleriyle Başkanlık Sarayı önüne yürümüşlerdir. Sarayın çevresinde toplanan halk, darbeci hükümeti adeta ablukaya almış haldedir. Durumu gören saray muhafizları da halkın yanında yer almış ve darbecilere karşı bir operasyon hazırlığına başlamıştır. Bu noktada Başkanlık Sarayı'nın kapısındaki bir askerin kısa bir süre için kolunu kaldırıp dışarıdaki halkın sloganına eşlik ettiği de görülmektedir. Ardından saray muhafizları operasyona başlar. Bu sırada darbecilerin de telaşlı biçimde kaçmaya çalıştıkları görülmüştür. Operasyon neticesinde askerler Başkanlık Sarayı'nı ele geçirmiş ve halkı selamlamışlardır.

$\mathrm{Bu}$ durum en başından beri medya desteğini yanında göremeyen ancak halkla ve askerlerle iletişimi güçlü olan, halkı anayasal hakları konusunda bilgilendirmek için çeşitli çalışmalar yapan Chavez ve ekibinin bunda başarılı olduklarını göstermektedir. Zira halk seçtiği lidere ve onayladığı anayasaya sahip çıkmıştır. Medyanın uyguladığı yanlı ve yalan habercilik kamuoyunun düşüncesinin oluşmasında etkili olmamış, halk hakkını aramak amacıyla sokakları dökülmüştür. Bu tepkiyi gören ordu da, halkın yanında yer alarak seçilmiş başkan ve anayasayı manipülasyonlarla alaşağı etmek isteyen darbecileri engellemiştir. Daha sonra Başkanlık Sarayı'nı yeniden ele geçiren Chavez yönetimi, onun serbest kalması ve ülkenin diğer kesimlerinde asayişin sağlanması ve ordunun Chavez'e tamamen itaat etmesi için devlet televizyonu Kanal 8'in kontrol altına alınması çalışmalarını başlatmıştır. Bu amaçla yapılan girişimler neticesinde Kanal 8 geri alınır ve halka durumun kontrol altına alındığı bilgisi iletilir. Bu esnada sarayda yayını izleyen Chavez'in Bakanlar Kurulu Üyeleri ve başkanlık ofisi çalışanları "El pueblo unido jamas sera vencido" "7 sloganını atarak, sevinç gösterileri yaparlar. $\mathrm{Bu}$ bağlamda ele alındığında medyanın manipülasyon amaçlı değil de halkı bilgilendirmek amaçlı kullanılmasının ne denli önemli olduğu ortaya çıkmaktadır. Diğer yandan devlet televizyonu, iktidarın söylemini ürettiği, aynı zamanda da onun ontolojik bir kanıtı olarak var olduğu bir mecradır. Dolayısıyla devlet televizyonunun hem simgesel hem de işlevsel bir önemi bulunmaktadır.

Belgeselde daha sonra Chavez'in gözetim altında olduğu adadan getirilmesi için yapılan çalışmalar gösterilir. Bu çalışmalar ve yoğun telefon trafiği neticesinde sabaha karşı 02.50 de Chavez'i taşıyan helikopterin 1şığı görülür. Saray çevresinde halk onu coşkulu bir şekilde ellerinde Venezuela bayrakları ile sevgi gösterisi yaparak karşılamaya hazırlanmaktadır. Başkanlık Sarayı'nın aydınlatılmış pistine iniş yapan Chavez, askeri bando eşliğinde karşılanır ve sol yumruğu havada bir şekilde halkı selamlar.

Buradaki görüntülerde de yine 1şık ve karanlık vurgusu göze çarpmaktadır. Gece karanlığında bir araca bindirilerek, yine karanlıklar içine doğru yol alan Chavez, adeta kutsal ya da mitolojik bir kahraman gibi gece karanlığında gökyüzünden ışık saçarak inmiş ve halkın arasına karışmıştır. Halkın kendisine olan sevgisi ve bağlılığı, onu karanlıklardan geri getirmeye muktedir olmuştur. Diğer yandan yine Hristiyan inancındaki Hazreti İsa'nın çarmıha gerilerek öldükten 3 gün sonra dirilmesi inancı ve Rönesans dönemi ressam ve heykeltıraşlarının İsa'nın dirilişi konulu eserleri ile görsel bakımdan benzerlik gösteren bu olay; demokrasi ve halk iradesinin gücüne de kutsallık kazandıran bir anlam taşımaktadır.

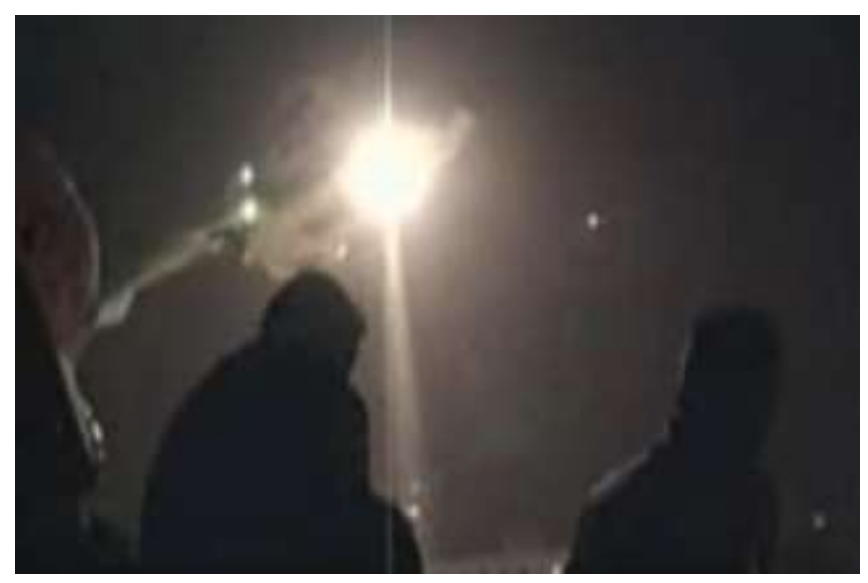

Görsel.6)The Revolution Will Not Be Televised belgeselinden bir kare

Chavez'in halkı selamlarken havaya kaldırdığı sol yumruk ise iktidarı geri almanın bir sevinç gösterisi olmasının dışında, ideolojik açıdan da Venezuela'da sosyalizmin zafer kazandığını göstermektedir.

Belgesel Chavez'in onlarca basın mensubu önünde yaptığı ve halkı sükûnete ve anayasaya saygıya çağırdığı açıklamaların ardından darbe girişiminde öncü olan isimlerin akıbetleri ile ilgili bilgilerin verildiği ve en sonunda da Venezuelalı üç gencin neşeli bir biçimde söyledikleri şarkıyla sona ermektedir. $\mathrm{Bu}$ görüntülere bakıldığında ise Chavez ve

${ }^{7}$ İsp. Birleşen halkı hiçbir güç yenemez. 
ekibinin yaşadıkları bu olayların ardından olgun davrandıkları, sükûnet ve sorumluluk içinde oldukları gösterilirken, belgesinin bitiminde yine siyah fon üzerine küçültülmüş bir ekran içinde darbecilerin akıbetleri anlatılmıştır. Burada da onların artık Venezuela siyasetinde ve dolayısıyla tarihinde etkin birer figür olamayacakları, önceden televizyonlarda tam ekran görüntüleri verilirken, artık boyutsal olarak da kapladıkları alanın küçüldüğü de ve etkisizleştikleri görülmektedir. Bu görüntülerin siyah fonda verilmesi onların en başından beri yanılgı ve korku içinde olduklarını ve bu hislerin onları küçülterek, çevrelerini kapladığını ve kaçmak zorunda kaldıklarını göstermektedir. En sonda, aydınlık bir havada birbirine sarılıp, neşeli biçimde şarkı söyleyen üç genç ise ülkenin bu sıkıntılı süreci atlatarak gelecekte daha mutlu, huzurlu ve toplumsal barış içinde günler göreceğine yapılan bir göndermedir.

\section{Karşılaştırma ve Sonuç}

Her iki belgeselde demokrasi dışı güçlerin, demokratik seçimler sonucu göreve gelmiş siyasal iktidara müdahalesini ve bunun halk desteğiyle başarısız kılınması süreci anlatılmaktadır. Bu bağlamda coğrafi, kültürel, toplumsal, tarihsel ve siyasal bakımdan çok farklı iki toplum, demokratik tercihlerine karşı yapılan hukuksuz eylemleri kabul etmemiş ve iradesini ortaya koymuştur.

Her iki belgesel de darbe girişimi esnasında yaşananları ekrana getirmiştir. 15 Temmuz Destanı belgeseli amatör kayıtlarla, bir sivil toplum kuruluşunun inisiyatifi sonucu derleme biçiminde ortaya çıkarılmışken, The Revolution Will Not Be Televised belgeseli farklı bir amaç için orada bulunan, profesyonel gazeteciler tarafından hazırlanmıştır. $\mathrm{Bu}$ nedenle olayların öncesi, sonrası, gelişimi, diğer görsel materyaller, belgeselin dramatik yapısı ve kurgusu da daha profesyonel görünmektedir.

Belgesellerde içerik bağlamında dikkat çeken bir diğer husus ise medyaya özellikle de televizyon kanallarına atfedilen önemdir. Venezuela'da 2002 yılında gerçekleşen darbe girişiminde sosyal medyadan ve onun etkisinden söz etmek için henüz erkendir. Bu nedenle halkın büyük oranda haber alma kaynağı geleneksel medya ve özel televizyon kanallarıdır. Bu kanalların yayın politikaları ise darbeye zemin hazırlamak amaciyla manipülatif haber ve programlar yapmak, gerçekleri saptırmak olmuştur. Medya üzerinde doğrudan bir denetimi ve devlet televizyonu haricinde etkili bir yayın organı olmayan Chavez bunun eksikliğini belgeselde de dile getirmiştir. Zira Başkanlık Sarayı'nı darbecilerden geri aldıktan sonra bile devlet televizyonu Kanal 8'in kontrolü için yoğun çaba harcanmış ve kontrol sağlandıktan sonra hiç vakit kaybetmeden halka bilgi aktarılmıştır. Bu süreçte dahi özel televizyonların durumu farklı aksettirdiği görülmüştür. Dolayısıyla medya, yaptığı haber ve yayınların dışında, yapmadıklarıyla da kamuoyunun düşüncesinin belirlenmesinde önemli bir araç olarak yer kaplamaktadır.

İki belgeselin bir diğer ortak noktası da halkın direnişlerinde bağımsızlık sembolü olan bayrağı kullanmayı tercih ettiğinin gösterilmesidir. Bunun yanı sıra belgesellerde yer verilen bayrak, ülkenin kurucularının tabloları ve dini göstergeler bu tür toplumsal olaylarda halkı birleştirebilecek her türlü manevi imgenin kullanıldığının göstergesidir. Bunun yanı sıra geniş halk kitlelerinin direniş görüntüleri, önemli ulusal mekânlar, askeri araç ve silah görüntüleri de darbe girişimlerinin ciddiyetini anlatmak için sıkça başvurulan göstergeler olmuşlardır.

Youtube ve benzeri video paylaşım sitelerine yüklenmesi bu belgeselleri, geleneksel medyanın belli bir yayın planı, ticari veya idari birtakım kısıtlamaları dışında, tüm kullanıcılar için açık, zaman ve mekân sınırlaması olmaksızın erişilebilen bir kaynak haline gelmesini sağlamıştır. Bu bağlamda dünya çapında günlük ortalama 30 milyon ziyaretçinin girdiği, seksene yakın dilde kullanım imkânı sağlayan ve kullanıcılarının \%60'1 aşan bir bölümü 18 - 44 yaş aralığında bulunan Youtube platformu; yalnızca video paylaşma özelliğiyle değil tarihsel, kültürel ve toplumsal olaylar hakkında görerek ve doğrudan bilgiye ulaşmak için kullanılan, böylelikle farkındalık ve taraftarlık oluşturma amacı taşıyan dijital aktivistlerin sıkça tercih ettiği bir mecra olmuştur.

Türkiye'de gerçekleşen 15 Temmuz Darbe girişiminin yaşandığ 2016 yılına ilişkin Digital in” 2017 Global Review ${ }^{8}$ raporuna göre ülkedeki aktif sosyal medya kullanıcısı yaklaşık 48 milyon kişi civarındadır. Darbe girişiminin başlangıcı ile çeşitli sosyal medya platformlarında bazı görüntüler ve iletilerin paylaşılması sosyal medya kullanıcı sayısının yükseldiğini kanıtlar niteliktedir. Diğer taraftan sosyal medyadaki paylaşımların darbe girişimine işaret ettiği Başbakan Binali Yıldırım tarafindan NTV televizyonuna yapılan canlı bağlantıyla teyit edilmiştir. Aynı şekilde daha sonra Cumhurbaşkanı Recep Tayyip Erdoğan, iktidar ve muhalefet partilerinin yetkilileri, çeşitli sivil toplum kuruluşların yöneticileri de geleneksel medya başta olmak üzere sosyal medyadan da halka seslerini duyurmuşlar ve bu girişime direnmeleri çağrısında bulunmuşlardır. Venezuela'nın aksine hem geleneksel medya kuruluşları hem de aradan geçen zaman ve teknolojik gelişmelerle artan, yaygınlaşan sosyal medya araçları vasıtasıyla halk kendi arasında da iletişim sağlayıp, örgütlenerek hızlı bir direniş gerçekleştirmiştir. Burada dikkat çeken bir önemli nokta da sosyal medya uygulamalarının teknolojisi ve mobil olma özelliği sayesinde geleneksel medya tarafından etkili biçimde kullanılmasıdır.

Darbe girişimi esnasında Cumhurbaşkanı Recep Tayyip Erdoğan'ın önce Periscope uygulaması ile internet üzerinden, ardından Facetime uygulaması ile CNN-TÜRK televizyonunun canlı yayınına bağlanarak halkı bilgilendirmesi ve darbenin püskürtülmesindeki önemli etkisi de, sosyal medya ve geleneksel medyanın güç elde etme organizasyonunda birleşik bir aygıt vazifesi görebileceğini göstermiştir. Diğer yandan yeni medya ve geleneksel medyanın ortaklık ettiği mesajların güçlü bir etki alanı oluşturduğunu da ortaya koymaktadır.

Sonuç olarak söz konusu çalışmada, Türkiye ve Venezuela gibi kültürel ve siyasal açıdan iki farklı ülkede gerçekleştirilmek istenen benzer darbe girişimlerine ilişkin üretilen belgeseller incelenmiştir. $\mathrm{Bu}$ bağlamda çalışma, iletişim araçları ve görsel unsurların, toplumsal bir eylemde her iki kesim adına bir güç unsuru oluşturulmasına yardımcı olduğunu gösterirken diğer taraftan bu araçlar vasıtasıyla

${ }^{8} \mathrm{http} / / / \mathrm{www}$.dijitalajanslar.com/internet-ve-sosyal-medyakullanici-istatistikleri-2017/ 
üretilen görsel malzemenin toplumsal hatırlamaya yardımcı olacak çeşitli imgeleri taşıdığını öne çıkarmaktadır. Bunu yaparken de tarihi, kültürel ve dini değerlerin toplumsal bütünlüğün sağlanmasında kullanılan önemli unsurlar olduğu görülürken, bu değerler bütününün sunumu ve toplumsal yönlendirmenin sağlanmasında sosyal medya ve geleneksel medya gibi araçların üretimlerinin etkin bir mecra olarak kullanıldığını ortaya koymaktadır.

\section{Kaynakça}

Adanır, O. (2003). Sinemada Anlam ve Anlatım. İstanbul: Alfa Yay.

Aziz, A. (2007). Siyasal İletişim. ankara: Nobel Yay.

Barthes, R. (1979). Göstergebilim Illkeleri. (B. Vardar, \& M. Rifat, Çev.) Ankara: 1979.

Castells, M. (2012). Ağ Toplumunda İletişim, İktidar ve Karş1 İktidar . Yeni Medya Üzerine. içinde Antalya: Akdeniz Üni. İletişim Araştırma ve Uygulama Merkezi Yay. .

Çilingir, A., \& Dursun, Z. (2017). Belgesel Sinemada Toplumsal Bellek Oluşumu: "Ahıska Türkleri Sürgün" Belgeseli Örneği. Uluslararası Ahıska Türkleri Sempozyumu Bildiri KITABI (s. 349-356). Erzincan: Erzincan Üniversitesi Yay.
Gramsci, A. (2014). Hapishane Defterleri (7 b.). (A. Cemgil, Çev.) İstanbul: Belge Yay.

Ransom, D. (2006, Haziran 01). Inside the Venezuelan Revolution. Ocak 06, 2017 tarihinde www.newint.org: https://newint.org/features/2006/06/01/keynote/ adresinden alındı

Rifat, M. (1998). XX. Yüzyllda Dilbilim ve Göstergebilim Kuramları 1 Tarihçe ve Eleştirel Düşünceler. İstanbul: Yapı Kredi Yay.

Shoemaker, P., \& Reese, S. (2002). İdeolojinin Medya İçeriği Üzerindeki Etkisi. S. İrvan (Dü.) içinde, Medya Kültür Siyaset (s. 148). Ankra: Alp Yay.

Wertsch, J. V. (2015). Kolektif Bellek. P. Boyer, \& J. V. Wertsch içinde, Zihinde ve Kültürde Bellek (Y. A. Dalar, Çev., s. 169). İstanbul: Türkiye İş Bankası Kültür Yay.

Widgington, D. (2015). Video Aktivizmi İle İlgili Sıkça Sorulan Sorular. A. Langlois, \& F. Dubois (Dü) içinde, Otonom Medya (s. 126). İstanbul: Kafka Yay.

www.bbc.co.uk. (2016, Eylül 02). www.bbc.co.uk. Ocak 04, 2017 tarihinde Venezuela profile - Timeline: http://www.bbc.com/news/world-latin-america19652436 adresinden alınd 1

Yücel, H. (2013). Imgeden Yoruma. İstanbul: Ayrıntı Yay. 